\title{
Dichloro-Diphenyl-Trichloroethane (DDT) and Endosulfan in Sediments of Sabancuy Lagoon, Campeche, Mexico
}

\author{
Miguel Angel Ramírez-Elías ${ }^{*}$, Atl Victor Córdova-Quiroz ${ }^{1}$, Julia Griselda Cerón-Bretón' \\ Rosa María Cerón-Bretón', Jaime Rendón-von Osten², Javier Hipólito Cortés-Simón ${ }^{3}$ \\ ${ }^{1}$ Facultad de Química, Universidad Autónoma del Carmen, Ciudad del Carmen, México \\ ${ }^{2}$ Centro de Ecología, Pesquerías y Oceanografía del Golfo de México (EPOMEX), Universidad Autónoma de \\ Campeche, Campeche, México \\ ${ }^{3}$ Secretaria de Marina, V Zona Naval, Estación de Investigación Oceanográfica, Cd del Carmen, Campeche, \\ México \\ Email: "mramirez.unacar@gmail.com
}

Received 10 November 2015; accepted 12 January 2016; published 15 January 2016

Copyright (C) 2016 by authors and Scientific Research Publishing Inc.

This work is licensed under the Creative Commons Attribution International License (CC BY). http://creativecommons.org/licenses/by/4.0/

(c) (i) Open Access

\begin{abstract}
DDT and Endosulfan are persistent organic compounds which have been prohibited and their use has been limited in agricultural activities due to their toxicity, persistence and bioaccumulation potential. The use of DDT in fumigation campaigns against endemic diseases transmitted by vectors of malaria and dengue was prohibited in Carmen Island, Campeche, Mexico since 1995. In the surroundings of Sabancuy Lagoon, many and diverse agricultural activities are carried out and it is a common practice to use organ-chlorine pesticides as endosulfan. In order to know the levels of these compounds in this area, a sediment sampling campaign was carried out in ten sampling points randomly located within the Sabancuy Lagoon, Campeche and considering one reference sampling point located $2 \mathrm{~km}$ away from Sabancuy Lagoon within the Mexican Gulf. Three metabolites were identified in sediments samples belonging to DDT's family: (4,4'-DDD; 4,4'-DDE; 4,4'DDT) and Endosulfan's family (Endosulfan I, Endosulfan II y Endosulfan sulfate). Higher concentrations in DDT's family were found for 4,4'-DDD, followed by 4,4'-DDE and 4,4'-DDT. Endosulfan's family, showed the following order for concentrations: Endosulfan II > Endosulfan I > Endosulfan sulfate. Mean concentration for $\Sigma$-DDT and $\Sigma$-Endosulfan in Sabancuy Lagoon sediments was twice higher than those found in other studies carried out in Términos Lagoon, Campeche, Mexico in 2002.
\end{abstract}

\section{Keywords}

Organochlorine Pesticides, Pollution, Sabancuy, Coastal Lagoons

\footnotetext{
${ }^{*}$ Corresponding author.
}

How to cite this paper: Ramírez-Elías, M.A., Córdova-Quiroz, A.V., Cerón-Bretón, J.G., Cerón-Bretón, R.M., Rendón-von Osten, J. and Cortés-Simón, J.H. (2016) Dichloro-Diphenyl-Trichloroethane (DDT) and Endosulfan in Sediments of Sabancuy Lagoon, Campeche, Mexico. Open Journal of Ecology, 6, 22-31. http://dx.doi.org/10.4236/oje.2016.61003 


\section{Introduction}

Dichloro-Diphenyl-Trichloroethane (DDT) and Endosulfan are persistent organic compounds which belong to the organo-chlorine pesticides family (POC), compounds of great concern around the world for its chronic toxicity, persistence and bioaccumulation [1]. Such compounds represent potential threats to ecosystems and human health [2] [3]. POC's are known to persist in the environment long after its application and are able to experience atmospheric transport over long distances [4]-[8]. Chemical structure for DDT's isomers and Endosulfan's isomers is showed in Figure 1 and Figure 2, respectively [9] [10].

Although their production, use and disposal have been regulated or banned in most developed countries today they are still used in many developing countries [11]. In North America, POC's continue being detected in the environment despite its use was banned some decades ago [7].

In 2005, Mexico ranked sixth in the world for the use of DDT, accumulated in agriculture and was ranked in the fifth place for its use in the field of public health [12]. In 2003, it was estimated that between 1969 and 1979, 9000 tons of POC's were used, being the most popular DDT, toxafen, hexachloro-benzene, and endrin, among others [13]. Díaz-Barriga and collaborators reported similar trends: an annual usage of more than 4000 tons of DDT between the end of 1950's and the beginning of 1960's, followed by decrease and increase periods (especially due to its use in order to control of vector diseases) and showing a reduction in the end of 1990's [14].<smiles>Clc1ccc(C(c2ccc(Cl)cc2)C(Cl)(Cl)Cl)cc1</smiles>

p,p'-DDT<smiles>ClC(Cl)=C(c1ccc(Cl)cc1)c1ccc(Cl)cc1</smiles>

p,p'-DDE<smiles>Clc1ccc(C(c2ccc(Cl)cc2)C(Cl)Cl)cc1</smiles>

p,p'-DDD

(a)

(b)<smiles>Clc1ccc(C(c2ccccc2Cl)C(Cl)(Cl)Cl)cc1</smiles>

o,p'-DDT<smiles>ClC(Cl)=C(c1ccc(Cl)cc1)c1ccccc1Cl</smiles>

o,p'-DDE

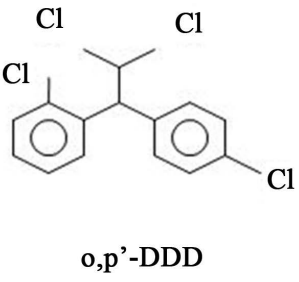

(c)

Figure 1. Chemical structures for DDT's isomers: (a) DDT, (b) DDE and (c) DDD.<smiles>O=S1OCC2C(Cl)C(Cl)(Cl)C(Cl)(Cl)C2CO1</smiles>

Endosulfan I ( $\alpha)$<smiles>O=S1OCC2C(O1)C1(Cl)C(Cl)=C(Cl)C2(Cl)C1(Cl)Cl</smiles>

Endosulfan II ( $\beta)$<smiles>O=S1(=O)OCC2C3COS(=O)(=O)C(Cl)(Cl)C(Cl)(C2CO1)C3(Cl)Cl</smiles>

Endosulfan sulfate

Figure 2. Chemical structures for Endosulfan's isomers: Endosulfan I $(\alpha)$, Endosulfan II $(\beta)$ and Endosulfan sulfate. 
The Environmental Cooperation Commission for North America [15] reported that the usage of DDT with public health purposes was reduced from 1,400 tons in 1993 to less than 600 tons in 1999. Under the Regional Action Plan for North America (PARAN), México agreed to eliminate in a gradual way the use of DDT for 2002 year; however, its complete elimination was accomplished in 2000 year [16] [17].

An air quality study was carried out in Chiapas, México, during the period from 2000 to 2001 [18] [19] and other studies were carried out in Belize and Central America, from 1995 to 1996 [20] and from 2000 to 2001, respectively [19]. All these studies reported high levels of DDT in those places; high levels of aldrín and dieldrin in Belize; and important concentrations of toxafen and endosulfan in Chiapas [7].

Coastal lagoons and estuaries are ecosystems that are affected in a negative form for POC's whose source is related to the urban growth, development, industrial and agricultural activities among others [21]. In coastal zones, the final destiny of persistent organic is aquatic bodies and coastal ecosystems [1] [22] [23]-[26]. Las lagunas costeras del Golfo de México se encuentran entre esos ecosistemas [1] [26]. Sabancuy Lagoon has an approximate area of $32 \mathrm{~km}^{2}$ and it belongs to a lagunar system named Términos-Pom-Atasta-Dead River. This lagoon is cursory with $1.5 \mathrm{~m}$ deep, and the mean channel through in a longitudinal and adjacent way to the continental edge with depths of up to $2 \mathrm{~m}$ [27].

DDT and Endosulfan were used until 1995 in the surroundings of Sabancuy Lagoon mainly in agricultural activities and fumigation campaigns against endemic diseases transmitted by vectors such as malaria and dengue. The most used pesticides in the past were DDT (99\% of the total volume), malation and fention. Particularly, in Campeche these pesticides were applied approximately in $25 \%$ of the total volume applied in the Southeast region of Mexico [1]. Currently, the use of pesticides has been increased in an uncontrolled way in the agricultural sector in developing countries, due to the need to raise the performance of new farmland and accelerate the production of fruits, vegetables, legumes and grasses; in order to satisfy the population demand in a global, regional and local levels; generating pollution of pesticides in sediments.

Under favorable conditions, sediments are sinks of POC, which can be resuspended and lead to a second round of water pollution [28]. Therefore, POC residues in pore water, suspended particles and sediments can provide valuable records that denote potential pollution and environmental hazards [3] [29].

Regarding to agricultural activities, in the cultivation of chile (Capsium annuum), the most used pesticides are malation, endosulfan and metamidofos, with a treated surface of almost $100 \%$. Most of the pesticides are applied in their whole (almost 90\%) between May and September being more intensive in chile cultivation though rice cultivation has the higher crop area and application rates [30].

Sabancuy climate is humid tropical warm type, which favors the main activities of the population, such as fishing and golf, with the rainiest month usually occurring in summer, with a maximum temperature of $36^{\circ} \mathrm{C}$ and an annual average of $26^{\circ} \mathrm{C}$ and an average temperature of the coldest month about $18^{\circ} \mathrm{C}$ with a variation of $5^{\circ} \mathrm{C}$ $7^{\circ} \mathrm{C}[31]$.

In the surroundings of Sabancuy Lagoon , agricultural activities are carried out considering different types of crops being the most important the papaya, Jalapeño chile jalapeño and vegetables cultivation; these activities contribute in a great manner in lixiviate of organochlorine pesticides such as DDT and Endosulfan, mainly. Therefore, the objective of this study was to determine the concentration levels of DDT and Endosulfan present in sediments of Sabancuy Lagoon, in Campeche, Mexico.

\section{Materials and Methods}

Sabancuy Lagoon is located within Carmen City municipality in Campeche, México, at the northeast Términos lagoon (18 $48^{\prime} 35^{\prime \prime} \mathrm{N}$ and $19^{\circ} 02^{\prime} 25^{\prime \prime} \mathrm{N}$ and $91^{\circ} 06^{\prime} 43^{\prime \prime} \mathrm{W}$ and $\left.91^{\circ} 26^{\prime} 56^{\prime \prime} \mathrm{W}\right)$ (Figure 3). Sabancuy lagoon has a permanent natural communication with sea at the northeast and has communication at southwest with La Aguada and Términos lagoons. Sabancuy laggon is additionally separated from the Gulf of Mexico by a sandy barrier parallel to the coast [27].

A strategic sampling was established considering the continental shelf of Sabancuy Lagoon, where the collection of superficial samples of sediment was carried out. This sampling included the urban bank within the lagoon and a reference sampling site located out of the lagoon. Eleven stations were considered which were distributed along the lagoon in the following manner: six stations were located before the continental shelf, three were located after the continental shelf where the urban influence is more evident, and one station was located in the mouth of the lagoon (where the bridge that connects the island with the continental zone is located) and fi- 


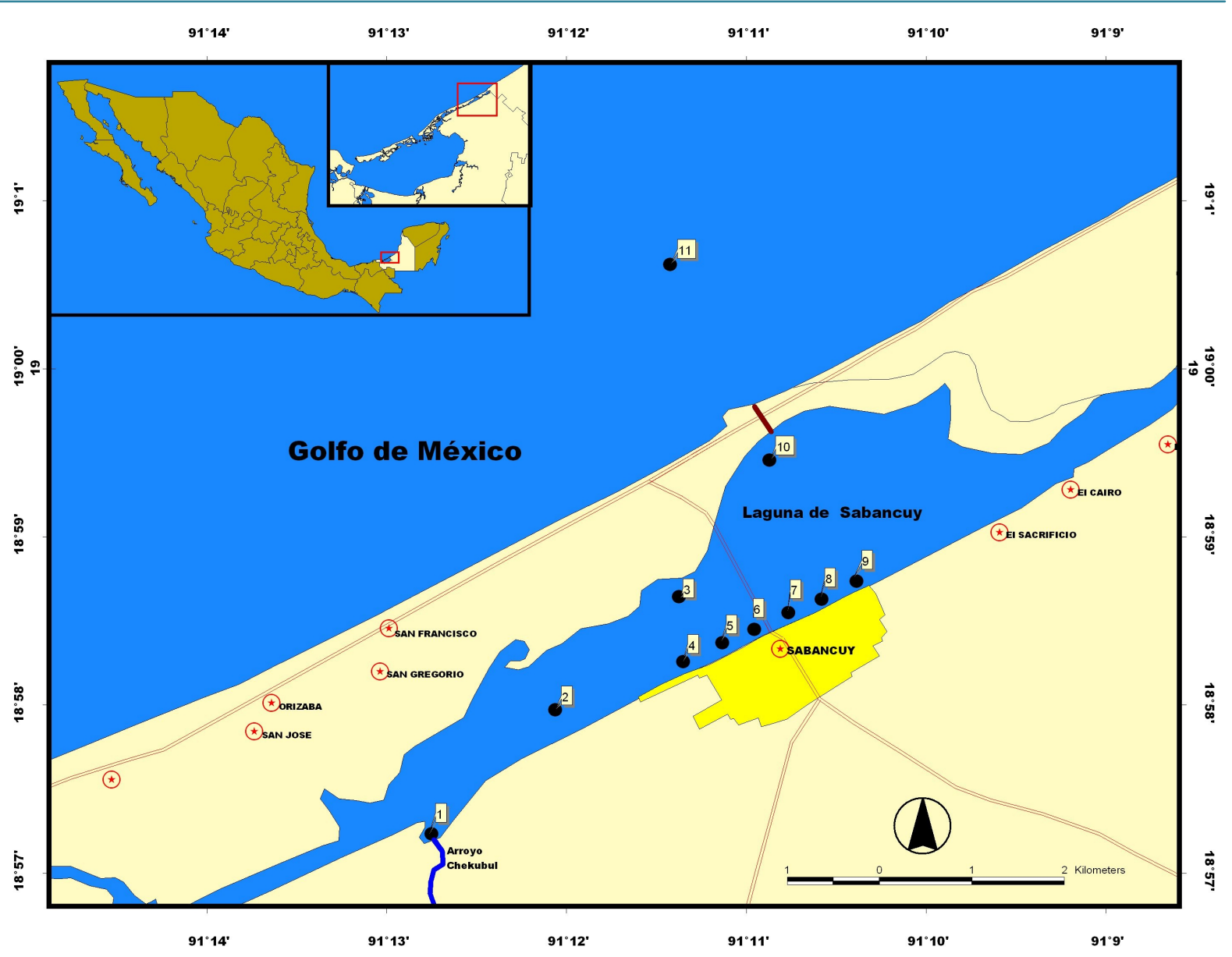

Figure 3. Location of sampling stations along the Sabancuy Lagoon in Campeche, México.

nally, a reference station was located in the outer edge of the Sabancuy Lagoon, at $2 \mathrm{~km}$ away from the Mexican Gulf (Figure 3).

The collection of superficial samples of sediment was carried out using a dredge Van Veen, collecting them in a direct way, in amber glass bottles previously treated, which were stored at low temperature $\left(4^{\circ} \mathrm{C}\right)$ and sent to the lab for analysis. Sediment samples were frozen and subsequently lyophilized with a Labconco Freeze Dry System. Once they were lyophilized, these were screened with a $0.5 \mu \mathrm{m}$ i.d. sieve mesh. The compounds of DDT and Endosulfan were determined for three seasons, according to the technique described by Sericano [32] and recognized by the National Status and Trends Program of the National Oceanic and Atmospheric Administration's (NOAA) in the laboratory of Environmental Sciences, College of Chemistry, University of Carmen City (UNACAR).

DDT and Endosulfan were quantified by gas chromatography using a Perkin-Elmer Gas Chromatography equipment XP Model with a capillary column CP-Sil 5 CB (with 100\% dimetil-polisiloxan, $25 \mathrm{~m} \times 0.15 \mathrm{~mm}$, and $1.2 \mu \mathrm{m}$ internal diameter), in a Split less mode and with an electron capture detector (ECD) [33]. Injector temperature was of $250^{\circ} \mathrm{C}$ and temperature in ECD was of $375^{\circ} \mathrm{C}$. Temperature program conditions were the following: $240^{\circ} \mathrm{C}$ for one minute, then temperature was increased until $270^{\circ} \mathrm{C}$ and it was maintain for two minutes, and finally, temperature was increased until $320^{\circ} \mathrm{C}$ and maintained for one minute. Nitrogen was used as carrier gas at $50 \mathrm{psi}$ pressure at $32.4 \mathrm{ml} \cdot \mathrm{min}^{-1}$.

\section{Statistical Analysis}

Statistical analysis was carried out using the non-parametric Kruskal Wallis statistical test in order to know if there were significant differences among groups and between mean values for DDT and Endosulfan, for the three seasonal sampling using the software Statistical 7.0 [34]. 


\section{Results and Discussion}

The results are presented for DDT and Endosulfan grouped in families with the same molecular weight or degradation product in the following way:

Dichloro-Diphenyl-Trichloroethane (DDT) $\rightarrow$ ¿DDTs = (4,4'-DDD + 4,4'-DDE + 4,4'-DDT).

Endosulfan $\rightarrow \Sigma$-Endosulfanes $=$ (Endosulfan I + Endosulfan II + Sulfate Endosulfan $)$.

\subsection{Temporal variation for Dichloro-Diphenyl-Trichloroethane (DDT).}

DDT's family in superficial sediments of Sabancuy Lagoon showed a maximum concentration for 4,4'-DDD of $1.920 \mathrm{ng} \cdot \mathrm{g}^{-1}$ during June (dry season) and a minimum value of concentration of $1.066 \mathrm{ng} \cdot \mathrm{g}^{-1} \mathrm{during}$ February (norths season); therefore, significant differences among seasons were found $(P<0.05)$. The highest inter-quartil rank was obtained for June which was typical for the dry season with a median of $1.900 \mathrm{ng} \cdot \mathrm{g}^{-1}$ and a mean value of $1.715 \mathrm{ng} \cdot \mathrm{g}^{-1}$ de 4,4'-DDD (Figure 4(a)).

Regarding to 4,4'-DDE, this compound showed too significant differences among seasons $(P<0.05)$, with a maximun concentration $1.912 \mathrm{ng} \cdot \mathrm{g}^{-1}$ during June (dry season) and a minimum value of $0.572 \mathrm{ng} \cdot \mathrm{g}^{-1} \mathrm{during}$ October (rainy season).

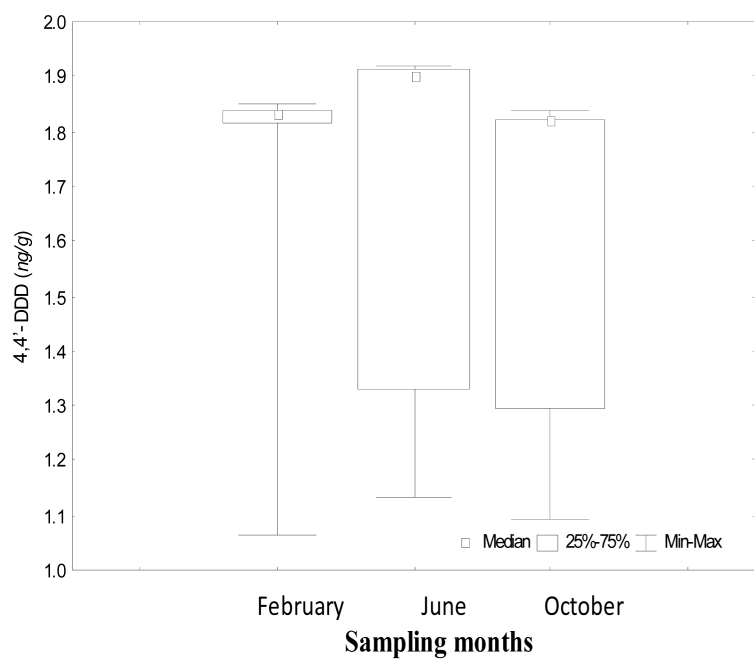

(a)

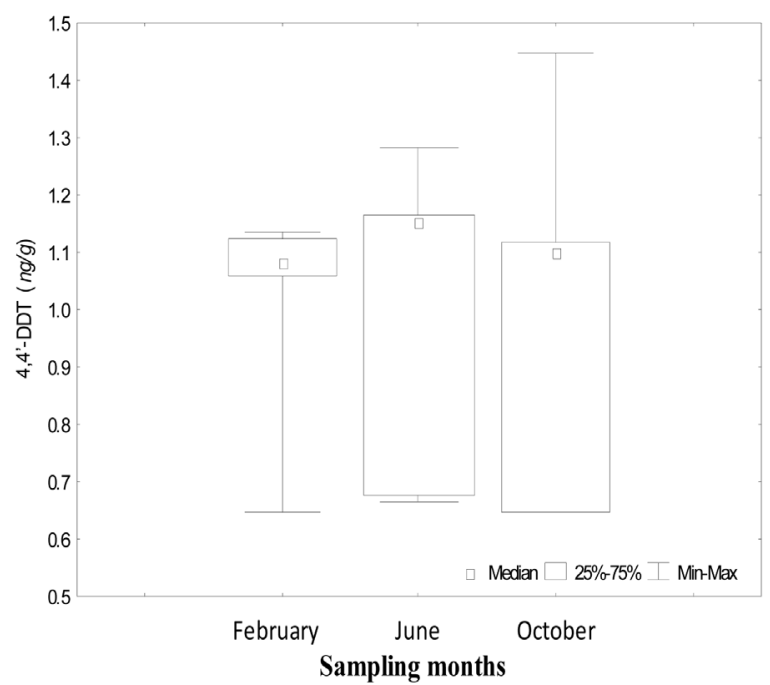

(c)

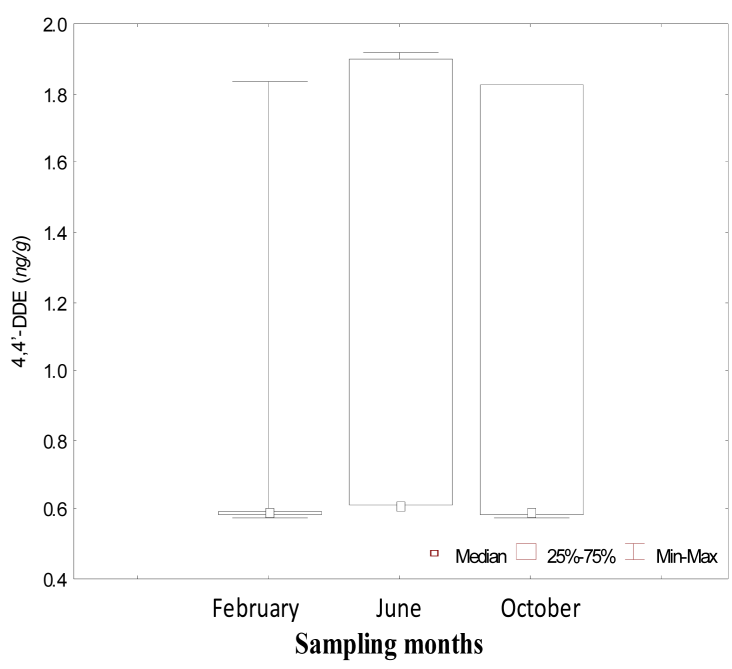

(b)

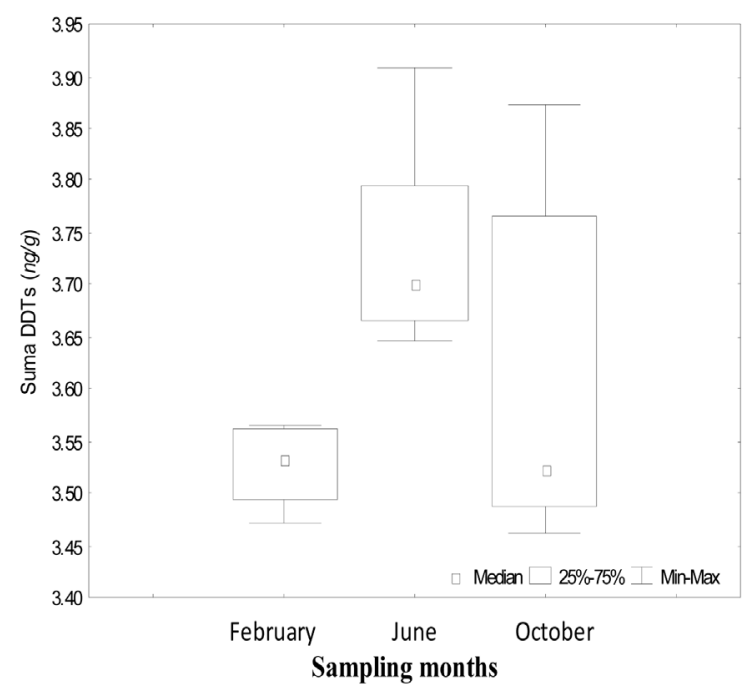

(d)

Figure 4. Temporal variation for (a) 4,4'-DDD; (b) 4,4'-DDE; (c) 4,4'-DDT; (d) $\Sigma$-DDTs expressed in ng.g ${ }^{-1}$. 
The highest inter-quartil rank was obtained during dry season with a median of $0.613 \mathrm{ng} \cdot \mathrm{g}^{-1}$ an a mean value of $0.965 \mathrm{ng} \cdot \mathrm{g}^{-1}$ for 4,4'-DDE (Figure 4(b)). 4,4'-DDT did not show significant differences among seasons, the maximum concentration was of $1.449 \mathrm{ng} \cdot \mathrm{g}^{-1}$ and the minimum value was of $0.644 \mathrm{ng} \cdot \mathrm{g}^{-1}$ during October (rainy season). The highest inter-quartil rank was obtained during dry season with a median of $1.152 \mathrm{ng} \cdot \mathrm{g}^{-1}$ and a mean value of $1.043 \mathrm{ng} \cdot \mathrm{g}^{-1}$ for 4,4'-DDT (Figure 4(c)). The statistical analysis of $\Sigma$-DTT showed significant differences $(P<0.01)$ among the months for each sampling season. Maximum and minimum concentrations for $\Sigma$-DTT were $3.907 \mathrm{ng} \cdot \mathrm{g}^{-1}$ and $3.460 \mathrm{ng} \cdot \mathrm{g}^{-1}$ during June and rainy season, respectively (Figure 4(d)). The highest interquartile-range was obtained for October with a median of $3.521 \mathrm{ng} \cdot \mathrm{g}^{-1}$ and a mean value of $3.593 \mathrm{ng} \cdot \mathrm{g}^{-1}$ for $\Sigma$-DTT.

DDT's were characterized by presenting the highest concentrations in June during the dry season and the lowest values in October during the rainy season; mainly in Sabancuy bridge zone where there is a greater flow of saline and fresh waters, during all the seasons (Norths, dry and rainy). The maximum concentrations for 4,4'-DDD and 4,4'-DDE during dry season (June) were found in sampling site $3\left(1.92 \mathrm{ng} \cdot \mathrm{g}^{-1}\right)$ and sampling site $10\left(1.9123 \mathrm{ng} \cdot \mathrm{g}^{-1}\right)$, respectively. $\Sigma$ DDT's concentrations were high too in the same sampling site with a maximum value of $3.9073 \mathrm{ng} \cdot \mathrm{g}^{-1}$. Therefore, according to the obtained results, degradation products of DDT's compounds family showed significant differences $(\mathrm{P}<0.05$ in both, sampling sites and climatic periods. Figure 5 shows obtained chromatograms for DDT's isomers (4,4'-DDD; 4,4'-DDE; 4,4'-DDT).

On the other hand, 4,4'-DDT had its maximum concentration $\left(1.449 \mathrm{ng} \cdot \mathrm{g}^{-1}\right)$ in October during the rainy season with a minimum value of $0.644 \mathrm{ng} \cdot \mathrm{g}^{-1}$. Higher concentrations for DDT's during dry season could be attributed to an increase in concentration in sediments due to they are sparingly soluble in water and highly persistent. Gil and Vale found a mean concentration of $2.27 \mathrm{ng} \cdot \mathrm{g}^{-1}$ for $\Sigma$-DDT in sediments of Tagus estuary (Portugal) [35], which are lower than those found in this study $\left(\Sigma-\mathrm{DDT}=3.61 \mathrm{ng} \cdot \mathrm{g}^{-1}\right)$ for sediments of Sabancuy Lagoon. On the other hand, a study carried out in 2004 in sediments of the Dongting Lagoon in China [36], reported the following mean values: $1.29 \mathrm{ng} \cdot \mathrm{g}^{-1}$ de 4,4'-DDD, $2.0 \mathrm{ng} \cdot \mathrm{g}^{-1}$ de 4,4'-DDE and $1.43 \mathrm{ng} \cdot \mathrm{g}^{-1}$ de 4,4'-DDT; comparing these values with those reported in the present study, it can be observed that in sediments of the Sabancuy Lagoon, 4,4'-DDE and 4,4'-DDT showed lower concentrations but it was found a higher concentration for 4,4'-DDD. Likewise, mean concentration for $\Sigma$-DDT Dongting Lagoon in China was of $5.31 \mathrm{ng} \cdot \mathrm{g}-1$, greater than that found in Sabancuy Lagoon in Campeche, Mexico $\left(3.61 \mathrm{ng} \cdot \mathrm{g}^{-1}\right)$.

Marine Secretary of Mexico (SEMAR) carried out a study in the Términos Lagoon System in Campeche, Mexico, it was found a mean value for $\Sigma$-DDT of $1.9466 \mathrm{ng} \cdot \mathrm{g}^{-1}$ [37], which is lower than the found value in Sabancuy Lagoon (3.6142 $\mathrm{ng} \cdot \mathrm{g}^{-1}$ ). According to the concentrations found in the Términos Lagoon [37] and comparing with those found in the present study, individual pesticides concentrations were quite lower. However, values for $\Sigma$-DDT and $\Sigma$-Endosulfan's in Sabancuy Lagoon were 1 - 2 times higher than those reported for

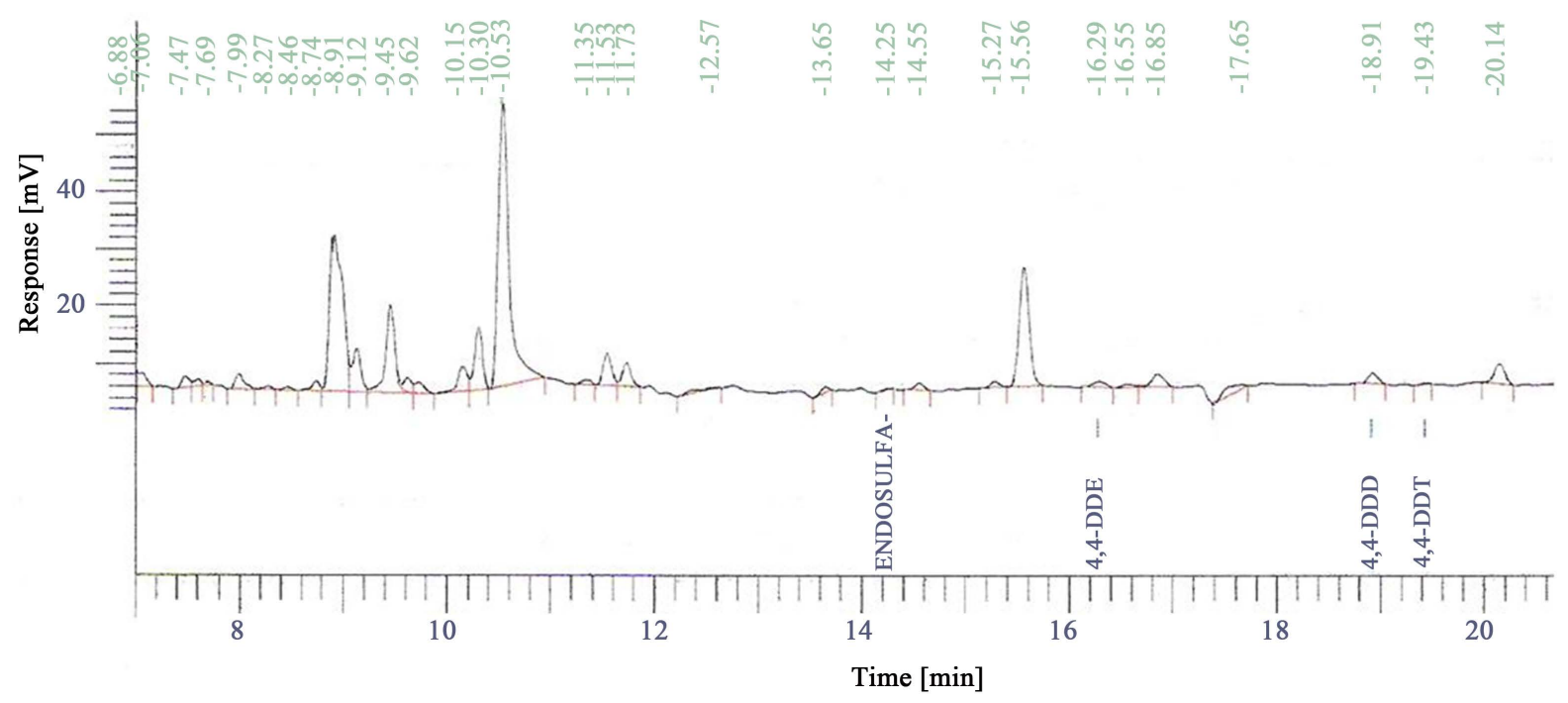

Figure 5. Typical obtained chromatograms for DDT's isomers (4,4'-DDD; 4,4'-DDE; 4,4'-DDT) and Endosulfan's isomers detected in Sabancuy Lagoon, Campeche, Mexico. 
Términos Lagoon probably due to an intensive use of DDT (since 1995) by the health sector and health jurisdiction of Carmen Municipality in campaigns against vectors such as dengue and malaria.

\subsection{Temporal Variation of Endosulfan}

Statistical analysis indicates that Endosulfans (I, II and sulfate) showed significant differences $(P<0.05)$ among months and seasons.

Endosulfan's family in sediments of Sabancuy Lagoon showed a maximum concentration for Endosulfan I in June with a value of $0.7036 \mathrm{ng} \cdot \mathrm{g}^{-1}$ (dry season) and a minimum of $0.5251 \mathrm{ng} \cdot \mathrm{g}^{-1}$ in October (rainy season). Likewise, the highest interquartile-range was obtained in June with a median of $0.698 \mathrm{ng} \cdot \mathrm{g}^{-1}$ and a mean value of $0.658 \mathrm{ng} \cdot \mathrm{g}^{-1}$ for Endosulfan I (Figure 6(a)).

For Endosulfan II, maximum concentration was of $0.713 \mathrm{ng} \cdot \mathrm{g}^{-1}$ in June (dry season) and a minimum value of $0.511 \mathrm{ng} / \mathrm{g}$ was found in October (rainy season). The highest interquartile-range was obtained in October with a median of $0.528 \mathrm{ng} \cdot \mathrm{g}^{-1}$ and a mean value of $0.565 \mathrm{ng} \cdot \mathrm{g}^{-1}$ for Endosulfan II (Figure 6(b)).

Sulfate Endosulfan presented a maximum concentration of $0.678 \mathrm{ng} \cdot \mathrm{g}^{-1}$ and a minimum value of $0.584 \mathrm{ng} \cdot \mathrm{g}^{-1}$ in February (Norths season). The highest interquartile-rage was obtained in June, during dry season, with a median of $0.673 \mathrm{ng} \cdot \mathrm{g}^{-1}$ and a mean value of $0.656 \mathrm{ng} \cdot \mathrm{g}^{-1}$ for Sulfate Endosulfan (Figure 6(c)). Statistical analysis for $\Sigma$-Endosulfanes presented significant differences $(P<0.01)$ among the different months for each climatic period. Maximum concentration for $\Sigma$-Endosulfanes was obtained in February with a value of $1.956 \mathrm{ng} \cdot \mathrm{g}^{-1}$ and a

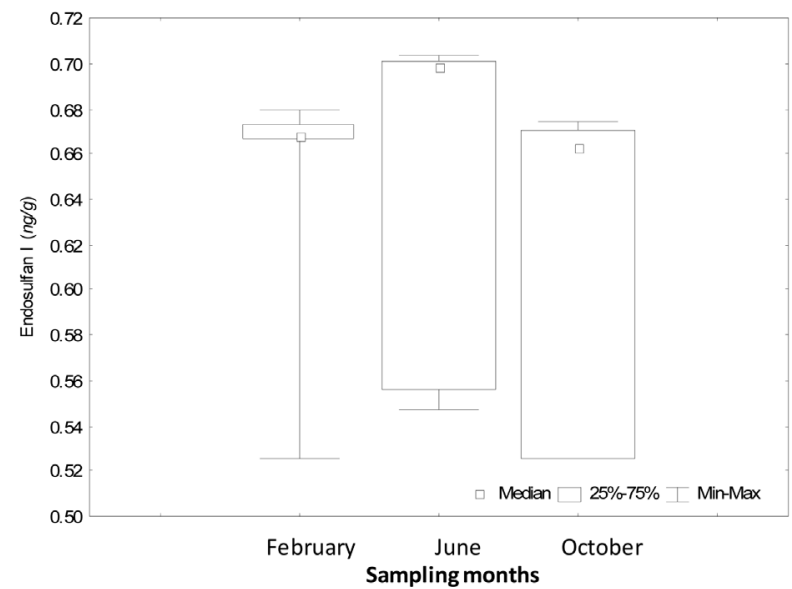

(a)

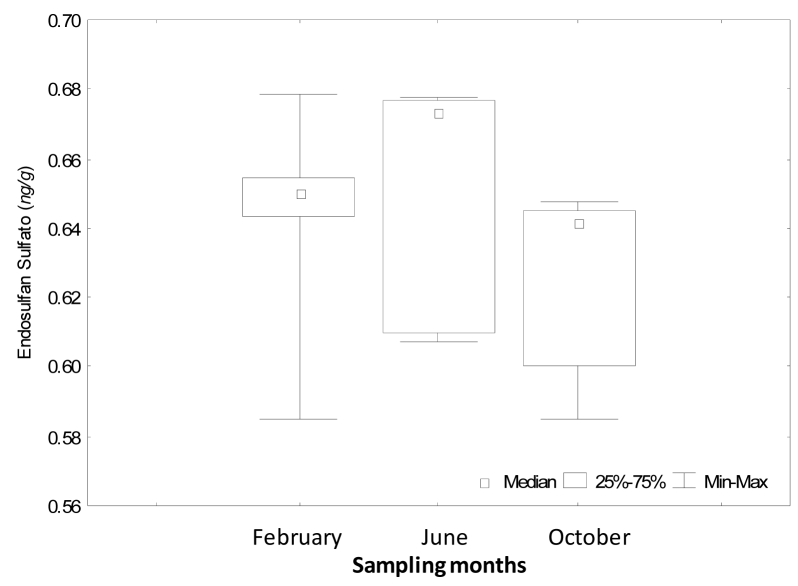

(c)

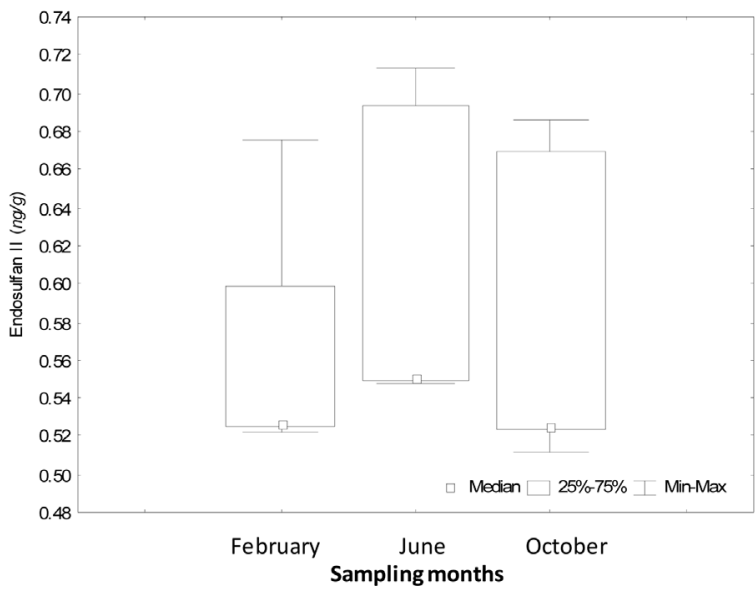

(b)

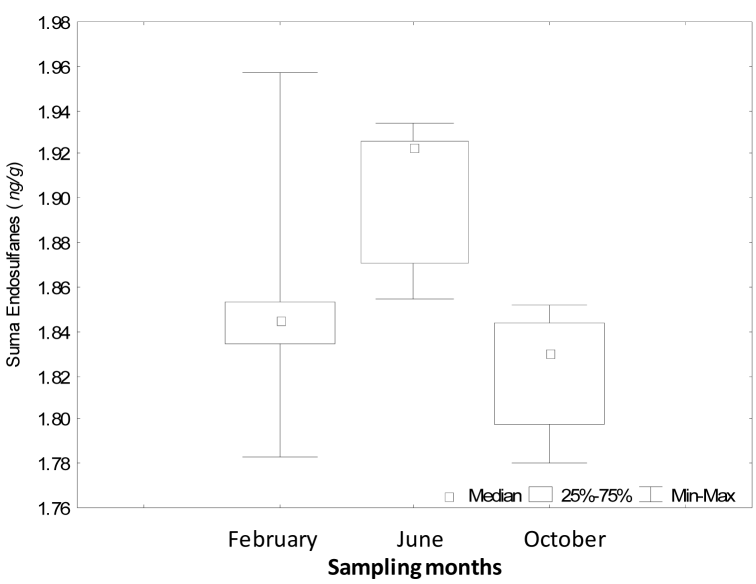

(d)

Figure 6. Temporal Variation for (a) Endosulfan I; (b) Endosulfan II; (c) Sulfate Endosulfan; (d) $\Sigma$-Endosulfanes expressed in $\mathrm{ng}^{-\mathrm{g}^{-1}}$. 
minimum value of $1.779 \mathrm{ng} \cdot \mathrm{g}^{-1}$ was obtained during the rainy season (Figure 6(d)). The highest interquartilerange was found in June with a median of $1.922 \mathrm{ng} \cdot \mathrm{g}^{-1}$ and a mean value of $1.907 \mathrm{ng} \cdot \mathrm{g}^{-1}$ for $\Sigma$-Endosulfanes.

Endosulfanes family are commonly used in pests control in agricultural activities [38], being their use more intensive during dry season in June, this is attributed to an increase in their concentration in sediments due to they are poorly soluble in water and very persistent at higher temperatures. Maximum concentration for Endosulfan I was of $0.7036 \mathrm{ng} \cdot \mathrm{g}^{-1}$ (in sampling site 3) and Endosulfan II presented its maximum value $\left(0.7137 \mathrm{ng} \cdot \mathrm{g}^{-1}\right)$ in sampling site 11, and the highest interquartile-ranges were found in dry season in sampling site 5 . Both Endosulfan sulfate as $\Sigma$-Endosulfanes presented their minimum and maximum concentrations during February in sampling site 6 with values of $0.6784 \mathrm{ng} \cdot \mathrm{g}^{-1}$ and $1.9562 \mathrm{ng} \cdot \mathrm{g}^{-1}$, respectively. Figure 5 shows obtained chromatograms for Endosulfan's isomers detected in Sabancuy Lagoon.

Therefore, according to obtained results, Endosulfanes family showed significant differences $(P<0.05)$ among sampling sites and climatic periods. In 1999, mean concentrations for Endosulfan I $\left(0.048 \mathrm{ng} \cdot \mathrm{g}^{-1}\right)$, Endosulfan II $\left(0.128 \mathrm{ng} \cdot \mathrm{g}^{-1}\right)$ and sulfate Endosulfan $\left(0.067 \mathrm{ng} \cdot \mathrm{g}^{-1}\right)$ were reported in sediments of Naranjo-Paso Caballos Lagoon in Nicaragua [22]. Comparing these results with those found in this study $(0.642,0.573$ and $0.641 \mathrm{ng} \cdot \mathrm{g}^{-1}$ ), respectively, it can be observed that there is a higher concentration for the Endosulfanes in Sabancuy Lagoon. On the other hand, in the study reported for Términos Lagoon in Campeche, Mexico, a mean value of $1.663 \mathrm{ng} \cdot \mathrm{g}^{-1}$ was found for $\Sigma$-Endosulfanes [37]. Comparing the found results in this study (1.857 $\mathrm{ng} \cdot \mathrm{g}^{-1}$ ) with those reported for Términos Lagoon study, it can be observed that higher concentrations for $\Sigma$-Endosulfanes were found in Sabancuy Lagoon probably due to its application and intensive use in the production of agricultural products as papaya and chili.

\section{Conclusion}

Endosulfanes family was dominant in dry season showing significant differences $(P<0.05)$ among sampling sites and climatic periods. Mean concentration for Endosulfanes presented the following relative abundance: $\Sigma$-Endosulfanes $>$ Endosulfan I > Endosulfan sulfate > Endosulfan II. Likewise, DDT's family was dominant and showed their maximum concentrations during dry season. As maximum concentrations for degradation products of DDT such as 4,4'-DDD and 4,4'-DDE are higher than the maximum concentrations for 4,4'-DDT, it can be concluded that its application in health campaigns against vectors such as malaria is not recent. It means that probably these compounds have been accumulated in the Lagoon during the last years. This agrees with the provided information by Sanitary Sector No. 3 of Carmen City, Campeche, indicating that DDT has not been used since 1995.

\section{References}

[1] Benítez, J.A. and Bárcenas, C. (2005) Patrones de uso de los plaguicidas en la zona costera del Golfo de México. In: Botello, A.V., Rojas-Galaviz, J.L., Benítez, J. and Zárate-Lomelí, D., Eds., Golfo de México, Contaminación e Impacto Ambiental: Diagnostico y Tendencias, EPOMEX Serie Científica 5, Universidad Autónoma de Campeche, México, 155-167.

[2] Xu, X., Yang, H., Li, Q., Yang, B., Wang, X. and Lee, F.S.C. (2007) Residues of Organoclhorine Pesticides in Near Shore Waters of LaiZhou Bay and JiaoZhou Bay, Sahndong Peninsula, China. Chemosphere, 68, 126-139. http://dx.doi.org/10.1016/j.chemosphere.2006.12.021

[3] Tan, L., He, M.C., Men, B. and Lin, C.Y. (2009) Distribution and Sources of Organochlorine Pesticides in Water and Sediments from Dalio River Estuary of Liaodong Bay, Bohai Sea (China). Estuarine Coastal and Shelf Science, 84, 119-127. http://dx.doi.org/10.1016/j.ecss.2009.06.013

[4] Wania, F. and Mackay, D. (1996) Tracking the Distribution of Persistent Organic Pollutants. Environmental Science \& Technology, 30, 390A-396A. http://dx.doi.org/10.1021/es962399q

[5] Gouin, T., Mackay, D., Jones, K.C., Harner, T. and Meijer, S.N. (2004) Evidence for the “Grasshopper” Effect and Fractionation during Long-Range Atmospheric Transport of Organic Contaminants. Environmental Pollution, 128, 139-148. http://dx.doi.org/10.1016/j.envpol.2003.08.025

[6] Tuduri, L., Harner, T., Blanchard, P., Li, Y.F., Poissant, L., Waite, D.T., Murphy, C. and Belzer, W. (2006) A Review of Currently Used Pesticides (CUPs) in Canadian Air and Precipitation: Part 1: Lindane and Endosulfans. Atmospheric Environment, 40, 1563-1578. http://dx.doi.org/10.1016/j.atmosenv.2005.11.034

[7] Alegría, H.A, Wong, F., Jantunen, L.M. and Bidleman, T.F., Salvador-Figueroa, M., Gold Bouchot, G., Ceja Moreno, V., Waliszewski, S.M. and Infanzon, R. (2002-2004) Organochlorine Pesticides and PCB in Air Southern Mexico. At- 
mospheric Environment, 42, 8810-8818. http://dx.doi.org/10.1016/j.atmosenv.2008.04.053

[8] Carvalho, P.N., Nuno, P., Rodrigues, R., Basto, M.C.P. and Vasconcelos, M.T.S.D. (2009) Organochlorine Pesticides Levels in Portuguese Coastal Areas. Chemosphere, 75, 595-600. http://dx.doi.org/10.1016/j.chemosphere.2009.01.060

[9] Rogan, W.J. and Chen, A. (2005) Health Risks and Benefits of Bis(4-chlorophenyl)-1,1,1-trichloroethane (DDT). Null, 366, 763-773. http://dx.doi.org/10.1016/S0140-6736(05)67182-6

[10] Castro, J., Perez, R.A., Miguel, E., Sanchez-Brunete, C. and Tadeo, J.L. (2002) Analysis of Endosulfan Isomers and Endosulfan Sulfate in Air and Tomato Leaves by Gas Chromatography with Electron-Capture Detection and Confirmation by Gas Chromatography-Mass Spectrometry. Journal of Chromatography A, 947, 119-127. http://dx.doi.org/10.1016/S0021-9673(01)01598-9

[11] Zhou, R., Zhu, L., Chen, Y. and Kong, Q. (2008) Concentrations and Characteristics of Organochlorine Pesticides in Aquatic Biota from Quiantang River in China. Environmental Pollution, 151, 190-199. http://dx.doi.org/10.1016/j.envpol.2007.02.015

[12] Li, Y.F. and Macdonald, R.W. (2005) Sources of Selected Organochlorine Pesticides in the Arctic and the Effect of Pathway Divergence on HCH Trends in Biota: A Review. Science of the Total Environment, 342, 87-106. http://dx.doi.org/10.1016/j.scitotenv.2004.12.027

[13] Gonzalez-Farías, F. (2003) Pesticides in the Coastal Zone of Mexico. In: Klaine, S.J., Carvalho, F.P., Barcelo, D. and Everaarts, J., Eds., Pesticides Residues in Coastal Tropical Ecosystems, Taylor \& Francis, London and New York, 311-337.

[14] Diaz-Barriga, F., Borja-Aburto, V., Waliszewski, S. and Yañez, L. (2003) DDT in Mexico. In: Fiedler, H., Ed., The Handbook of Environmental Chemistry, Springer-Verlag, Berlin, 371-388. http://dx.doi.org/10.1007/10751132_14

[15] NACEC (2001) History of DDT Use in North American to 1997. North American Commission for Environmental Cooperation, Montreal. http://www.cec.org/files/PDF/POLLUTANTS/HistoryDDTe_en.PDF

[16] NACEC (1997) North American Regional Action Plan for DDT. North American Commission for Environmental Cooperation, Sound Management of Chemicals, Montreal.

[17] NACEC (2003) DDT No Longer Used in North America. North American Commission for Environmental Cooperation, Montreal. http://www.cec.org/files/PDF/POLLUTANTS/DDT en.pdf

[18] Alegría, H.A., Bidleman, T.F. and Salvador-Figueroa, M. (2006) Organochlorine Pesticides in the Ambient Air of Chiapas, Mexico. Environmental Pollution, 140, 483-491. http://dx.doi.org/10.1016/j.envpol.2005.08.007

[19] Shen, L., Wania, F., Lei, Y.D., Teixeira, C., Muir, D.C.G. and Blideman, T.F. (2005) Atmospheric Distribution and Long-Range Transport Behavior of Organochlorine Pesticides in North America. Environmental Science \& Technology, 39, 409-420. http://dx.doi.org/10.1021/es049489c

[20] Alegría, H.A., Bidleman, T.F. and Shaw, T.J. (2000) Organochlorine Pesticides in the Ambient Air of Belize, Central America. Environmental Science \& Technology, 34, 1953-1958. http://dx.doi.org/10.1021/es990982b

[21] Zonta, R., Guerzoni, S., Pérez-Ruzafa, A. and de Jonge, V.N. (2007) Measuring and Managing Changes in Estuaries and Lagoons: Morphological and Eco-Toxicological Aspects. Marine Pollution Bulletin, 55, 403-406. http://dx.doi.org/10.1016/j.marpolbul.2007.09.003

[22] Carvalho, F.P., Montenegro-Guillen, S., Villeneuve, J.P., Cattini, C., Bartocci, J., Lacayo, M. and Cruz, A. (1999) Chlorinated Hydrocarbons in Coastal Lagoons of the Pacific Coast of Nicaragua. Archives of Environmental Contamination and Toxicology, 36, 132-139. http://dx.doi.org/10.1007/s002449900452

[23] Carvalho, F.P., Gonzalez-Farías, F., Villeneuve, J.P., Cattini, C., Hernandez-Garza, M., Mee, L.D. and Fowler, S.W. (2002) Distribution, Fate and Effects of Pesticides Residues in Tropical Coastal Lagoons of the Northwest of Mexico. Environmental Technology, 23, 1257-1270. http://dx.doi.org/10.1080/09593332308618321

[24] Taylor, M.D., Klaine, S.J., Carvalho, F.P., Barcelo, D. and Everaarts, J., Eds. (2003) Pesticides Residues in Coastal Tropical Ecosystems—Distribution, Fate, and Effects. Taylor \& Francis Publ., CRC Press, London, 576.

[25] Senthil Kumar, K., Sajwan, K.S., Richardson, J.P. and Kanan, K. (2008) Contamination Profiles of Heavy Metals, Polycyclic Aromatic Hydrocarbons and Alkylphenols in Sediments and Oyster Collected from Marsh/Estuarine Savannah GA, USA. Marine Pollution Bulletin, 56, 136-162. http://dx.doi.org/10.1016/j.marpolbul.2007.08.011

[26] Carvalho, F.P., Villeneuve, J.P., Cattini, C., Rendon, J. and Mota de Oliveira, J. (2009) Pesticides and PCB Residues in the Aquatic Ecosystems of Laguna de Terminos a Protected Area of the Coast of Campeche, Mexico. Chemosphere, 74, 988-995. http://dx.doi.org/10.1016/j.chemosphere.2008.09.092

[27] De la Lanza-Espino, G. and Cáceres-Martínez, C. (1994) Lagunas Costeras y Litoral Mexicano, Universidad Autónoma de Baja California Sur.

[28] Chau, K.W. (2005) Characterization of Transboundary POP Contamination in Aquatic Ecosystems of the Pearl River Delta. Marine Pollution Bulletin, 51, 960-965. http://dx.doi.org/10.1016/j.marpolbul.2005.02.028 
[29] Maldonado, C. and Bayona, J.M. (2002) Organochlorine Compounds in the North Western Black Sea Water: Distribution and Water Column Process. Estuarines, Coastal and Shelf Science, 54, 527-540. http://dx.doi.org/10.1006/ecss.2000.0672

[30] Botello, A.V., Rojas-Galaviz, J.L., Benítez, J. and Zárate-Lomelí, D. (1998) Golfo de México, Contaminación e Impacto Ambiental: Diagnóstico y Tendencias. Programa Sectorial de Medio Ambiente 1998-2005. Gobierno del Estado de Campeche. Secretaria de Ecología. Universidad Autónoma de Campeche, EPOMEX Serie Científica 5, 666 p.

[31] García, E. (1973) Modificaciones al sistema de clasificación climática de Koppen. Instituto Geología. UNAM, México, $264 \mathrm{p}$.

[32] Sericano, J.L., Atlas, E.L., Wade, T. and Brooks, J.M. (1990) NOAA’s Status and Trends Mussel Watch Program: Chlorinated Pesticides and PCBs in Oyster (Crassostrea virginica) and Sediments from the Gulf of Mexico, 1986-1987. Marine Environmental Research, 29, 161-203. http://dx.doi.org/10.1016/0141-1136(90)90033-k

[33] Perkin Elmer Nelson (1994) Gas Chromatography, Autosystem XL GC-User’s Manual.

[34] Statsoft Inc. (2004) Statistical (Data Analysis Software System), Version 7.0.

[35] Gil, O. and Vale, C. (1999) DDT Concentrations in Superficial Sediments of the Three Estuarine System in Portugal. Aquatic Ecology, 33, 263-269. http://dx.doi.org/10.1023/A:1009961901782

[36] Yong, Q., Minghui, Z., Bin, Z., Lirong, G. and Wenbin, L. (2004) Determination and Assessment of HCHs and DDTs Residues in Sediments from Lake Dongting, China. Environmental Monitoring and Assessment, 116, 157-167.

[37] SEMAR (2002) Distribución y comportamiento de plaguicidas organoclorados del sistema lagunar Términos, Campeche, México. Secretaría de Marina. Armada de México. Estación de Investigación Oceanográfica Carmen. V Zona Naval.

[38] CICLOPLAFEST (1997) Catalogo oficial de plaguicidas. México, 483 p. 